تحليل زنجيرهى عرضهى توتفرنكى در شهرستان راميان، استان كَلستان

\author{
مرضيه ميرى'، محمد شريف شريفزاده'، غلامحسين عبداللهزادهّو احمد عابدى سروستانى"
}

1- ارارشناس ارشد ترويج و آموزش كشاورزى

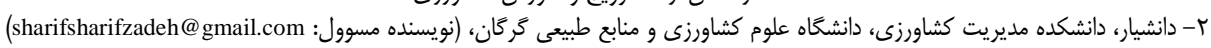

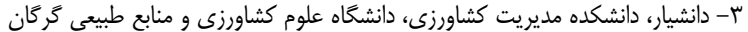

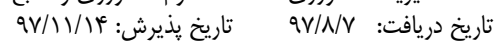

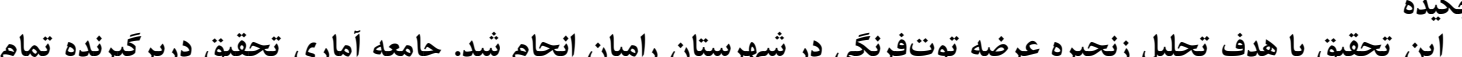

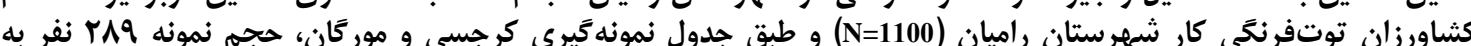

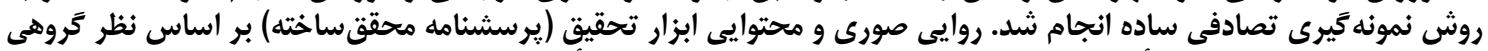

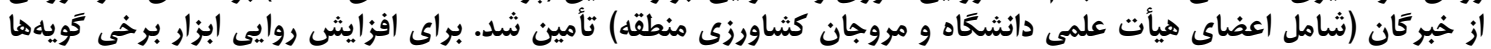

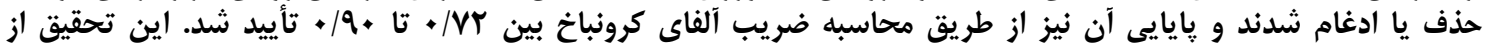

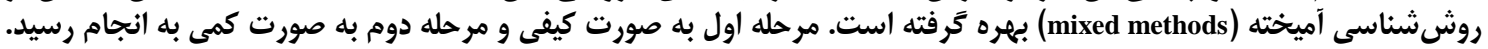

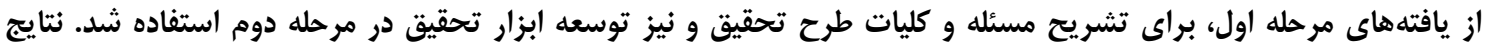

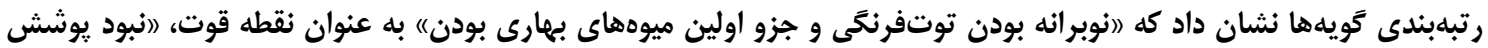

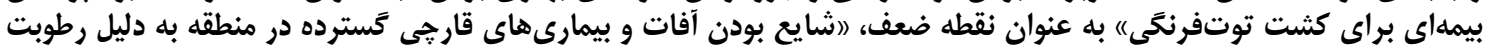

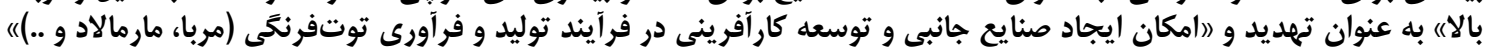

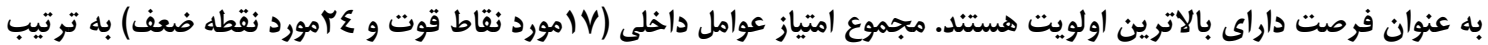

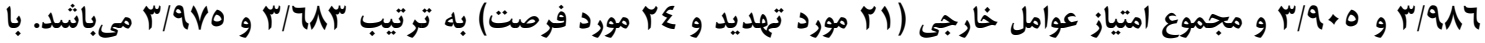

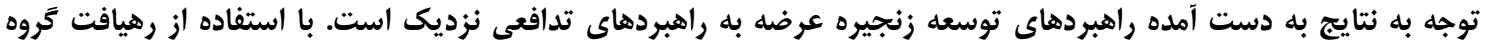

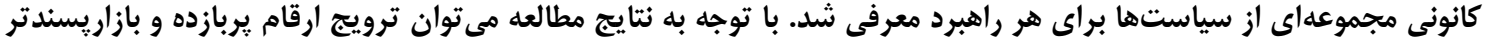

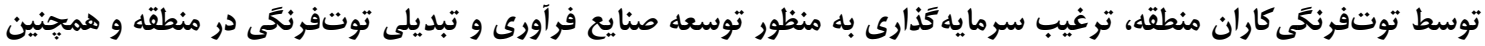

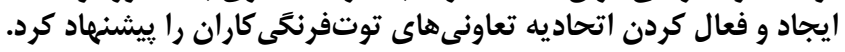

وازههاى كليدى: زنجيرهى عرضه، توتفرنتى، تحقيق آميخته، شهرستان راميان

محصولات به مصرفكنندكان خارجى داراى اهميت بالايى،

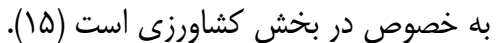

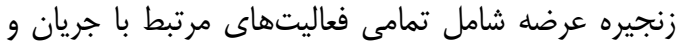

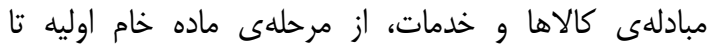

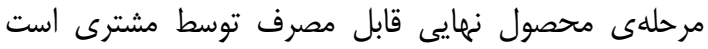

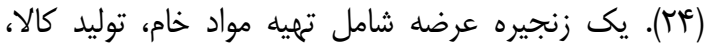

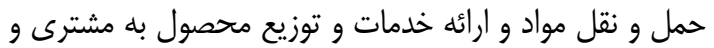

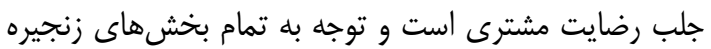

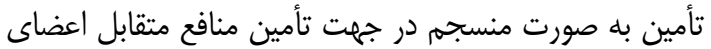

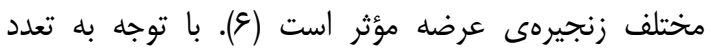

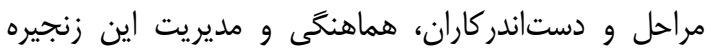

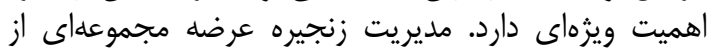

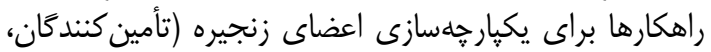

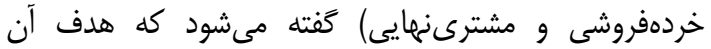

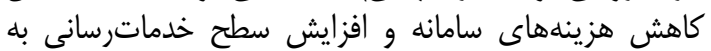

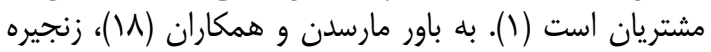

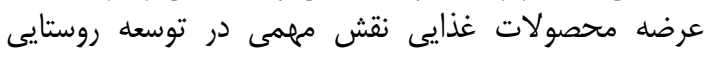

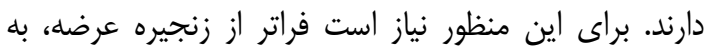

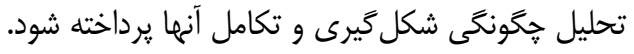

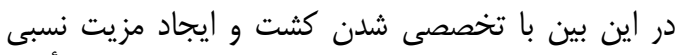

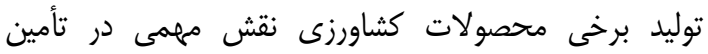
معيشت خانوارهاى روستايى ايفا كردهاند. در اين بئ بين
با وقوع انقاب صنعتى و ويشرفت فناورى تحولات بنيادى در بخشهاى مختلف توليد از جمله كشاون بناورزى صورت

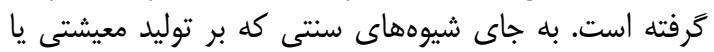

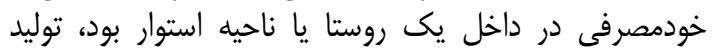

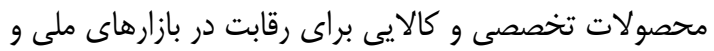

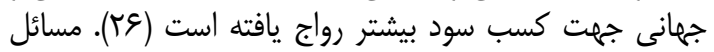

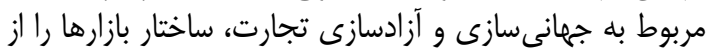

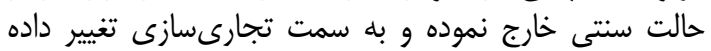

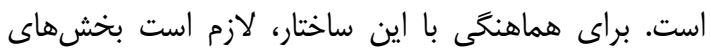

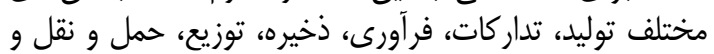

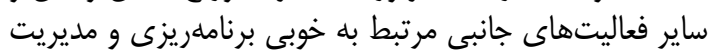

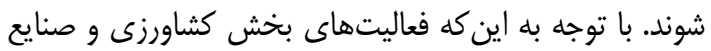

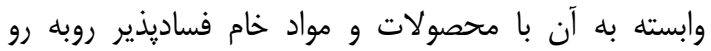
هستند، انتقال آنها از مزارع به محله آلهاى فرآ مآورى و انبارهاى

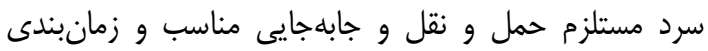
دقيق است. افزون بر اين اغلب مواد خام ونام و محصولات

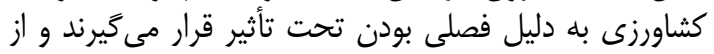

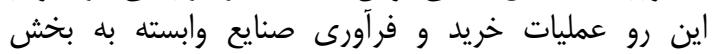

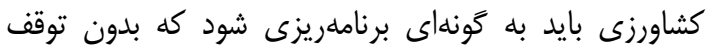

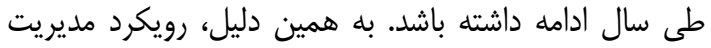

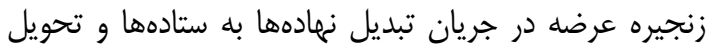


در استان كلستان با استفاده از تحليل SWOT، به اين نتيجه

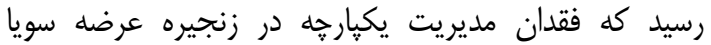

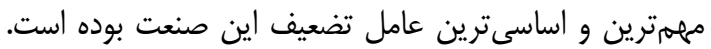

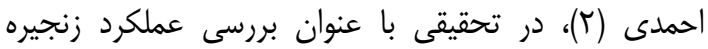

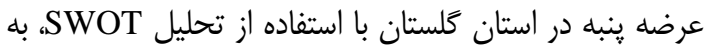

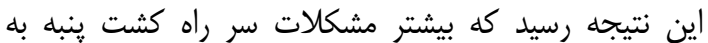

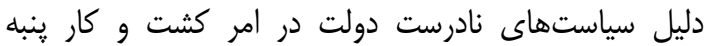

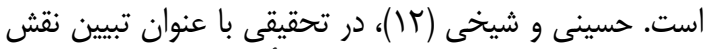

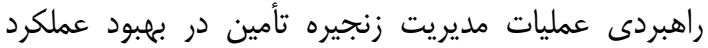

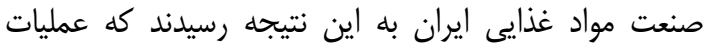

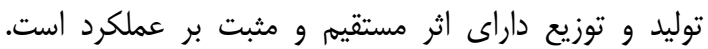

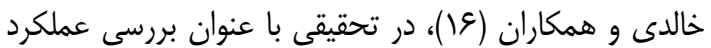

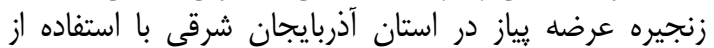

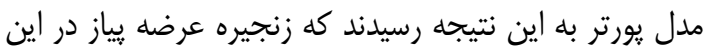

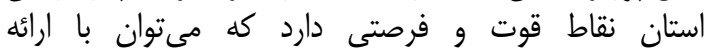

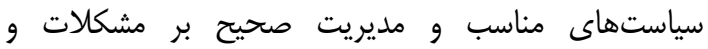

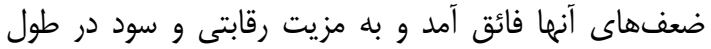

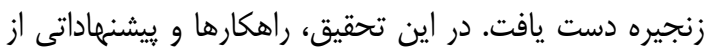

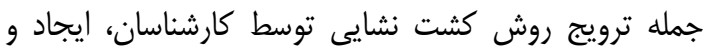

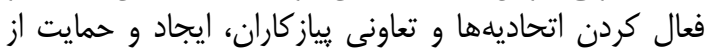

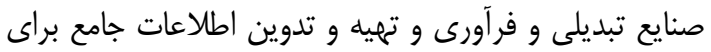

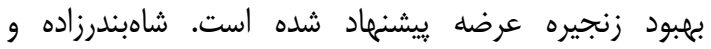

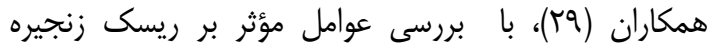

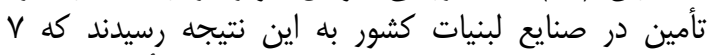

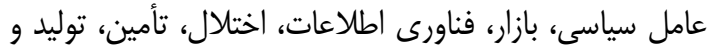

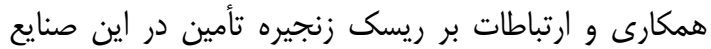

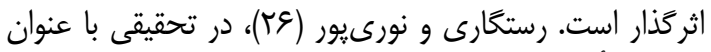

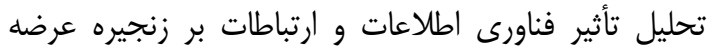

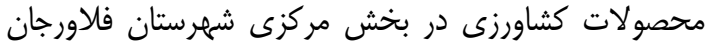

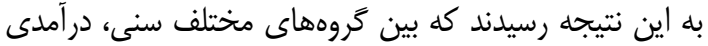

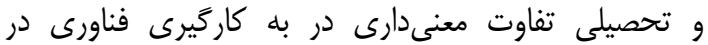

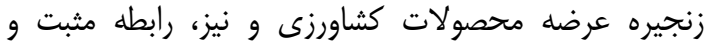

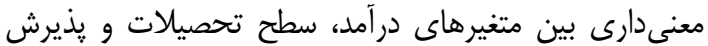

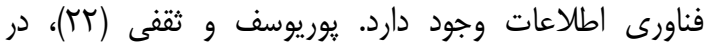

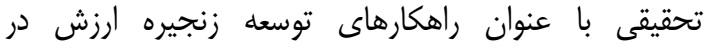

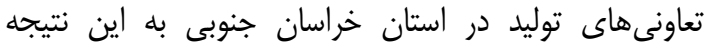

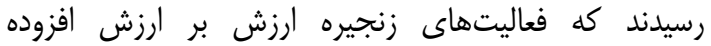
اقتصادى تأثير كذار است.

در خارج از كشور نيز تاكنون تحقيقات يرشمارى دارى درباره

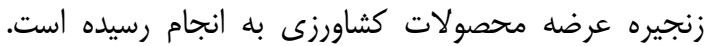

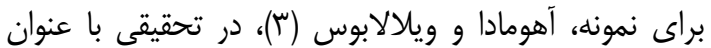

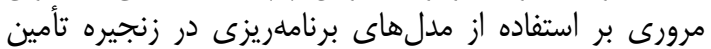

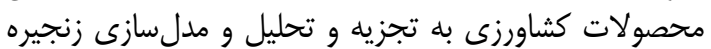

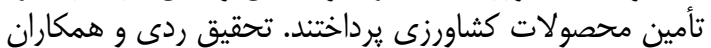

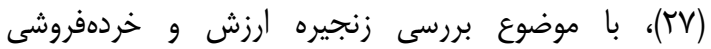

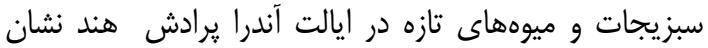

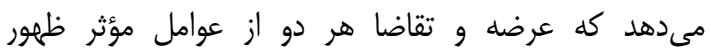

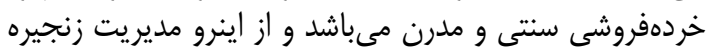

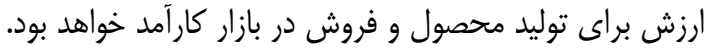

توتفرنكَى يكى از محصولاتى است كه در شهرستان راميان،

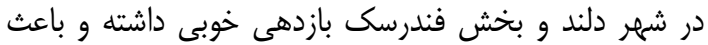

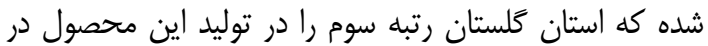

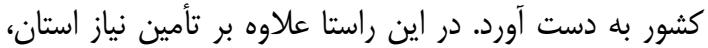

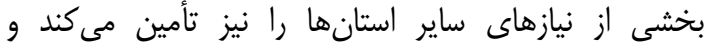

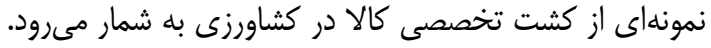

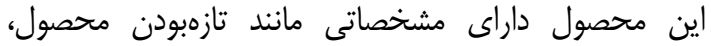

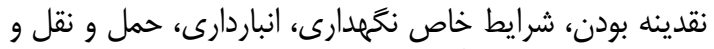

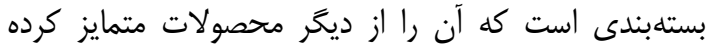

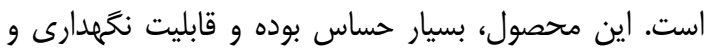

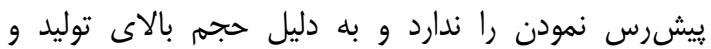

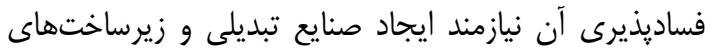

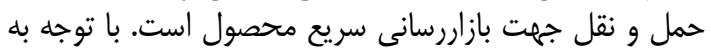

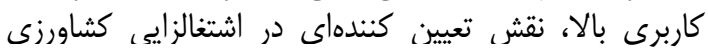

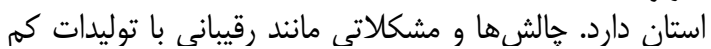

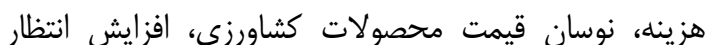

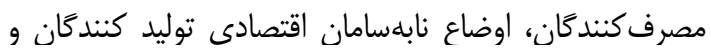

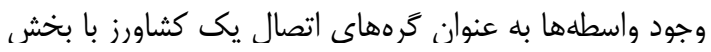

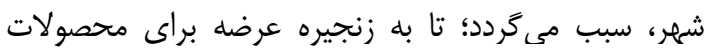
كشاورزى توجه ويزه لحاظ كردئ

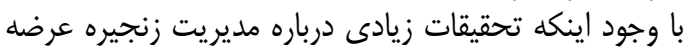

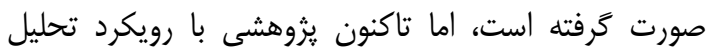

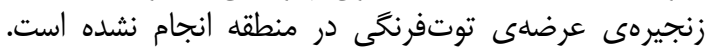

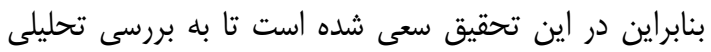

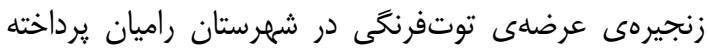

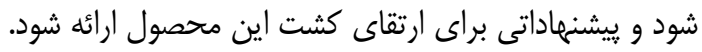

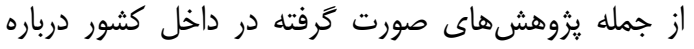

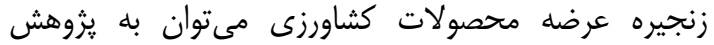

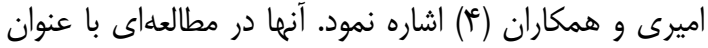

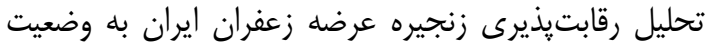

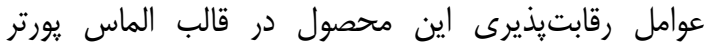

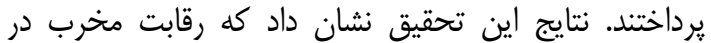

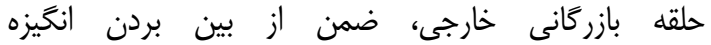

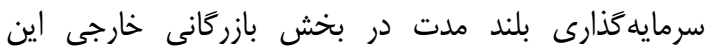

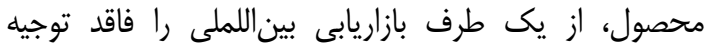

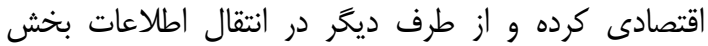

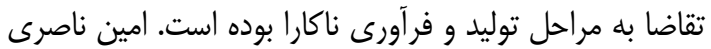

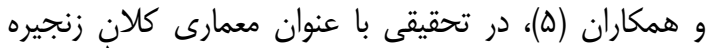

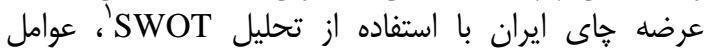

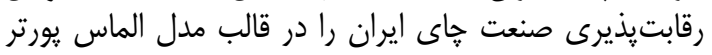

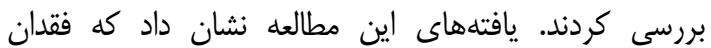

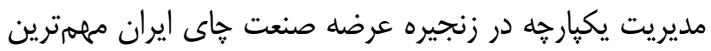

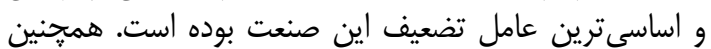

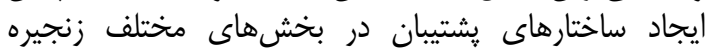

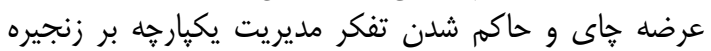

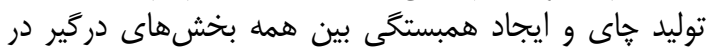

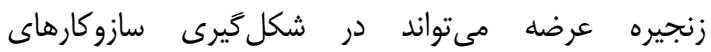

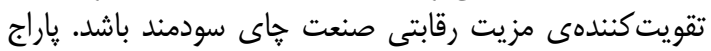

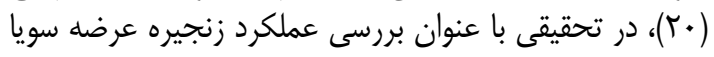




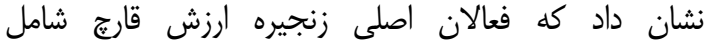

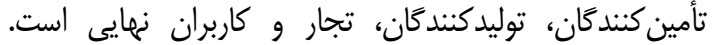

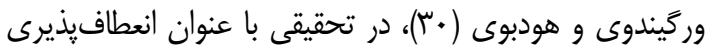

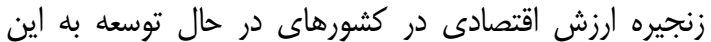

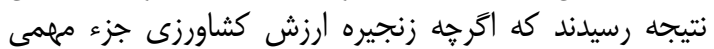

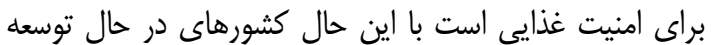

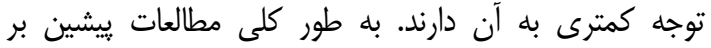

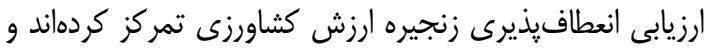

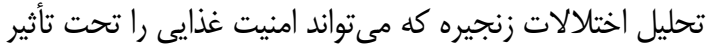

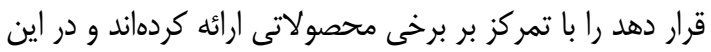

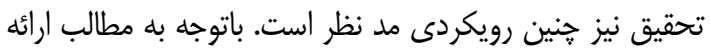

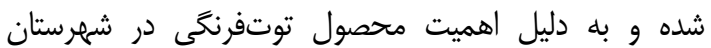

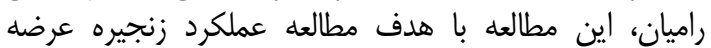

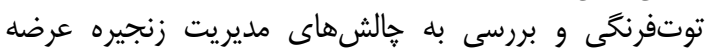

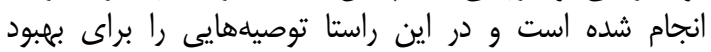

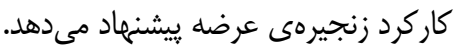

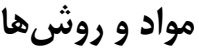

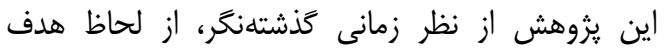

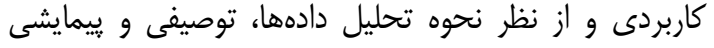

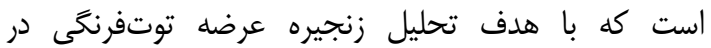

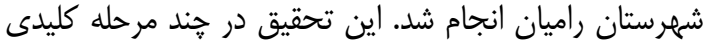

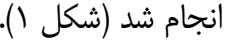

نتايج تحقيق جداو و همكاران (أ(ا)، با عنوان تجزيه و تحليل

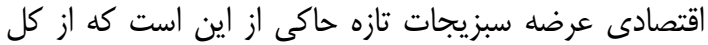

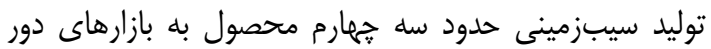

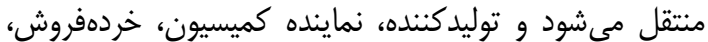

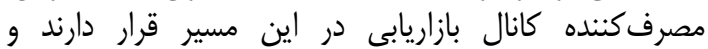

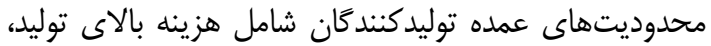

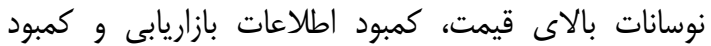

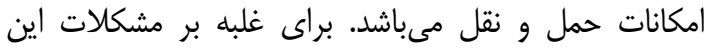

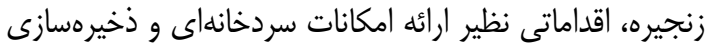

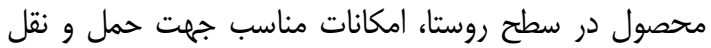

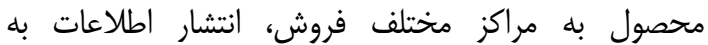

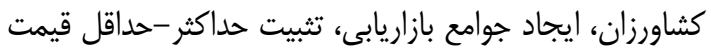

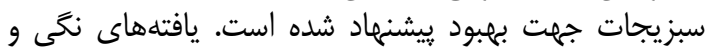

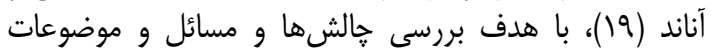

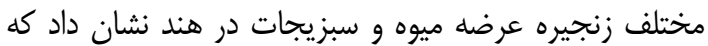

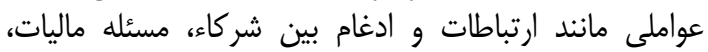

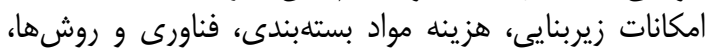

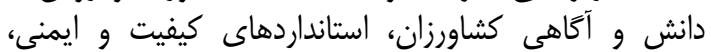

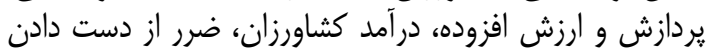

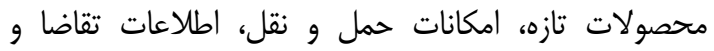

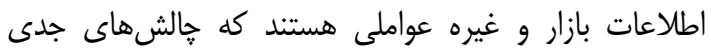

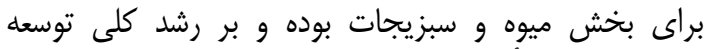

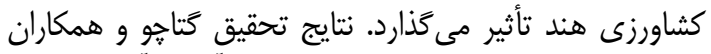
(9)، با عنوان تحليل زنجيره ارزش قارج در آديس آباباى اتيويى تانيى

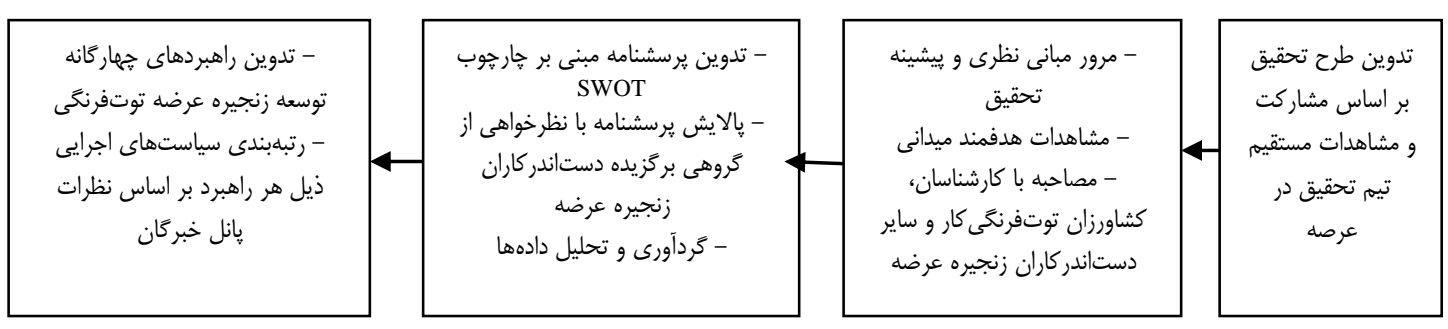

شكل 1- روند مراحل كلى تحقيق

Figure 1. The process of general research

بالاى توتفرنكى، تعدادى از كارشناسان جهادكشاورزى و

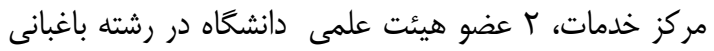

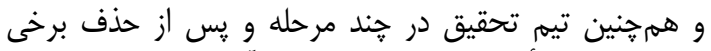

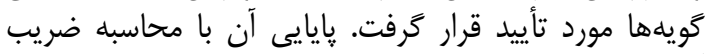
آلفاى كرونباخ مشخص مورد شايد (جدول () ().

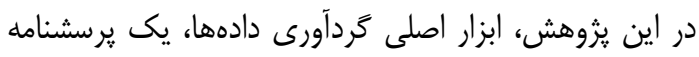

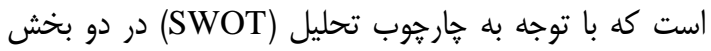

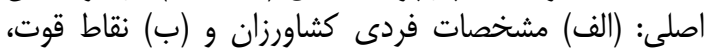

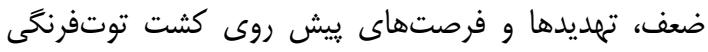

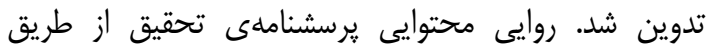

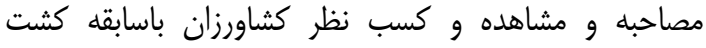


Table 1. Results from the reliability of the key sections of the questionnaire

جدول 1- نتايج آزمون پايايى براى بخشهاى كليدى يرسشنامه

\begin{tabular}{|c|c|c|c|}
\hline ضرايب آلفاى & كويهذاد & كويههاى پالايش شده در مرحله روايىسنجى & 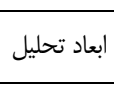 \\
\hline.$/ \mathrm{N}$ & IV & 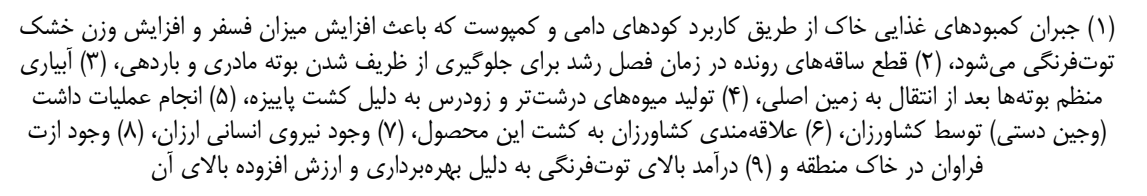 & نقاط قوت \\
\hline$\cdot / V V \Delta$ & re & 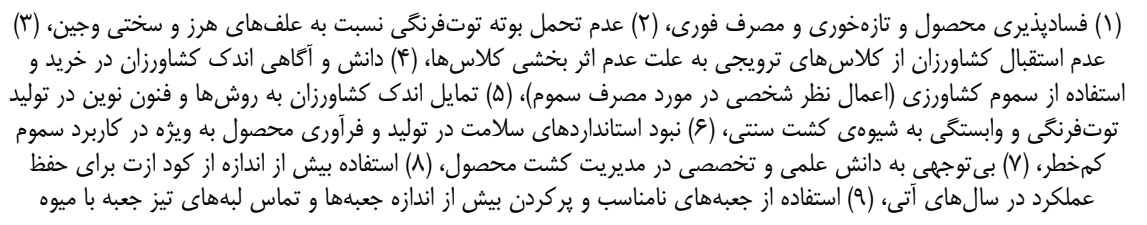 & نقاط ضعف \\
\hline$\cdot / V r s$ & rI & خشكسالى و كمبود آب & ت تهديدها \\
\hline$\cdot / 9 \cdot 1$ & re & 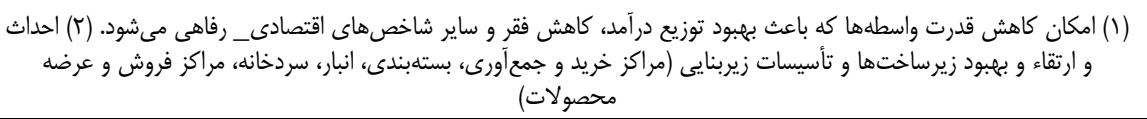 & فرصتها \\
\hline
\end{tabular}

تهديدها، وزندهى و اولويتبندى اين نقطه نظرات صورت

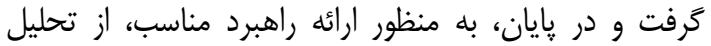

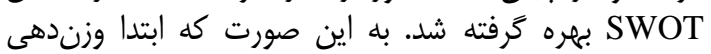

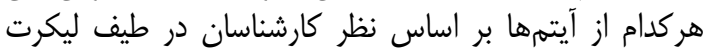

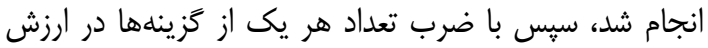

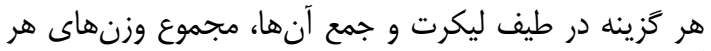

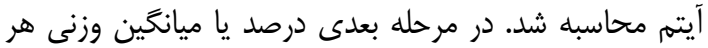

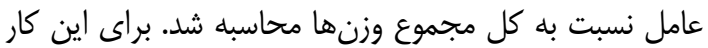

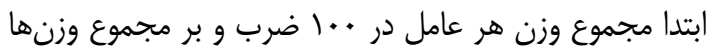

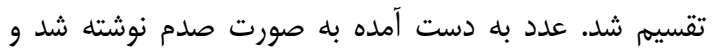

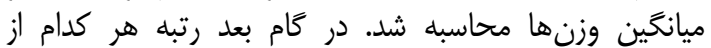

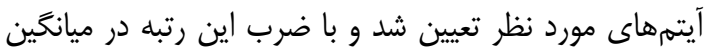

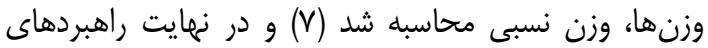
مورد نظر تدوين و ارائه كرديد.

بحث و نتايج

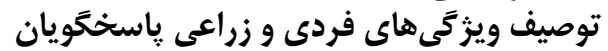

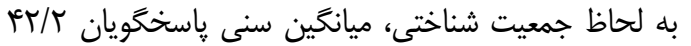

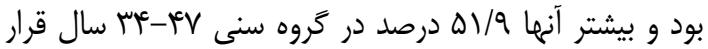

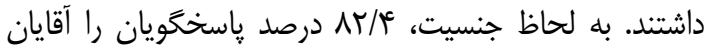

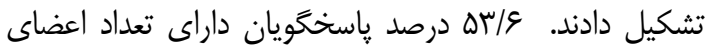

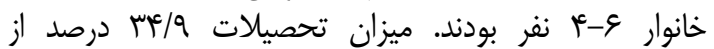

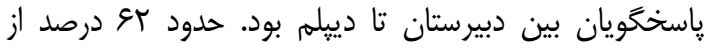

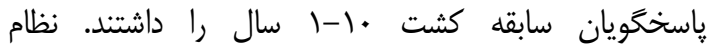

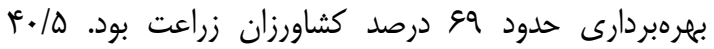

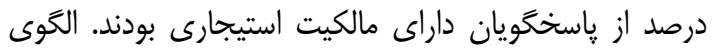

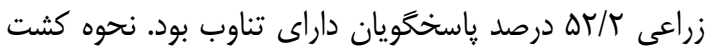

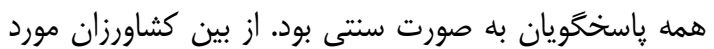

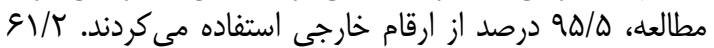

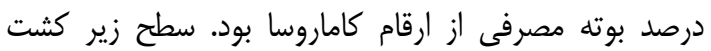

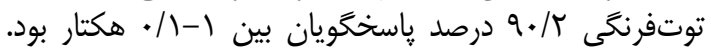

جامعه آمارى اين تحقيق شامل كشاورزان مشغول به

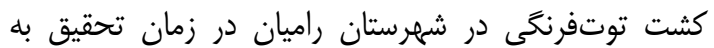

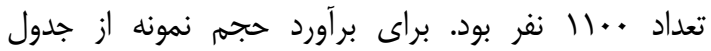

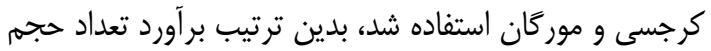

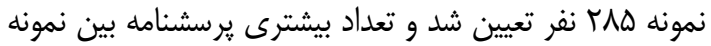

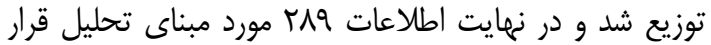

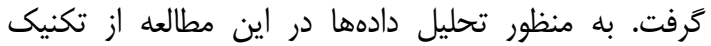

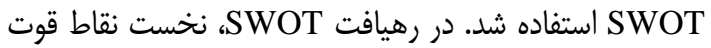

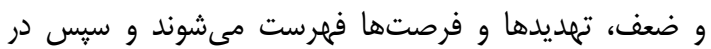

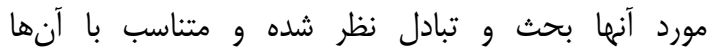

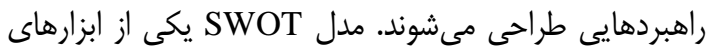

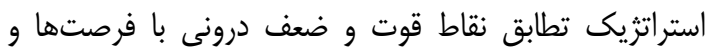

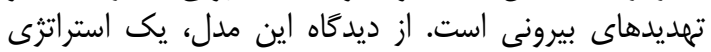

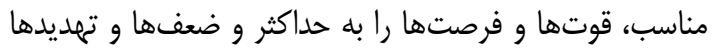

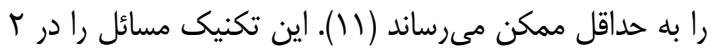

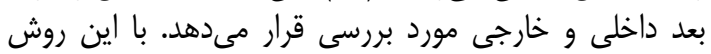

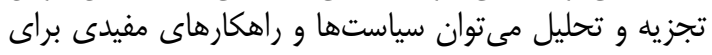

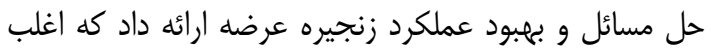

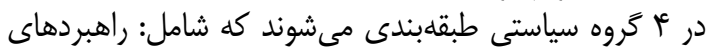
So

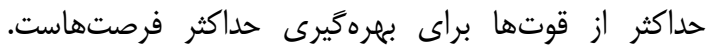

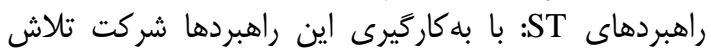

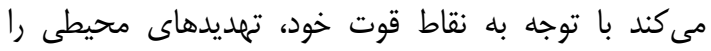
خنثى كند. راهبردهاى WO

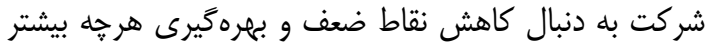

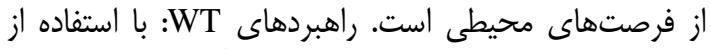

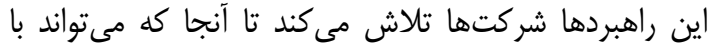

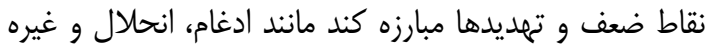

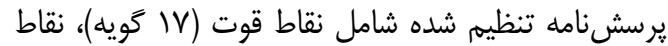

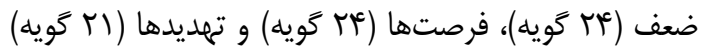
بود. يس از استخراج و جمعبندى نقاط قوت، ضعف، فر فر 
عامل را نسبت به مجموع كل به دست آورد كه براى اين كار

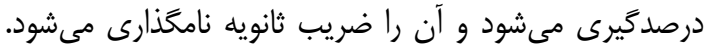

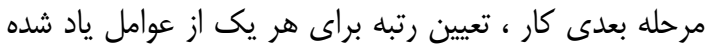

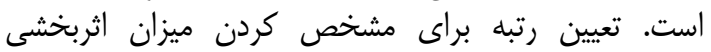

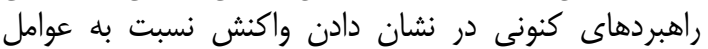

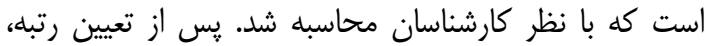

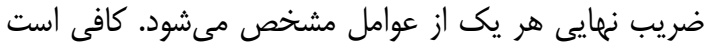

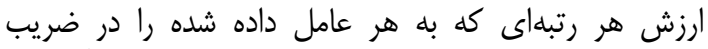

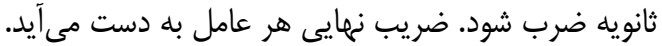

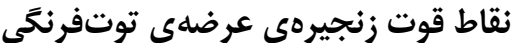

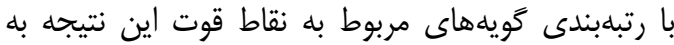

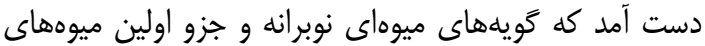

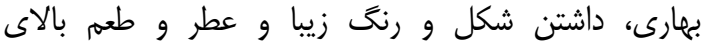

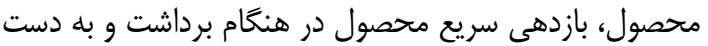

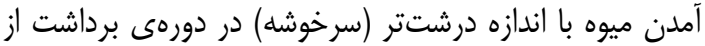
رتبه بالاترى برخوردارند.

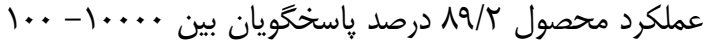

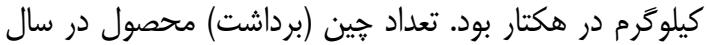

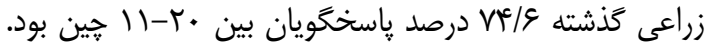

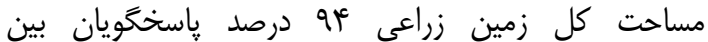

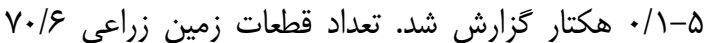

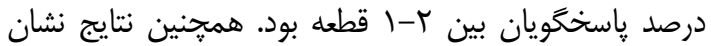

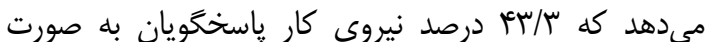
تلفيقى (خانوادگى و روزمزدى) است. وضعيت زنجيره عرضه توتفرنگى در منطقه مورد مطالعه

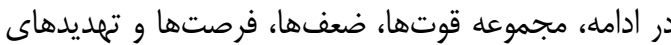

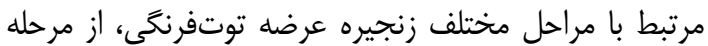

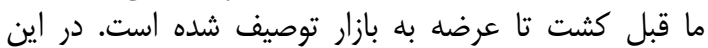

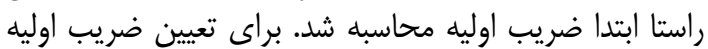

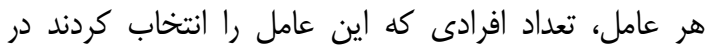

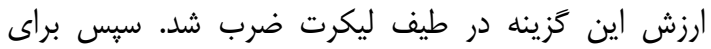

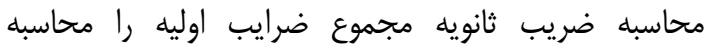
مىشود. حال در مرحله بعدى بايد درصد يا ميانكين وزنى هر مراسيه

Table 2. Ranking the strengths of strawberry supply chain

جدول r- رتبلبندى نقاط قوت زنجيرهى عرضهى توتفرنكى

\begin{tabular}{|c|c|c|c|c|}
\hline 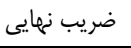 & رتبه & ضريب ثانويه & ضريب اوليه & كويdها \\
\hline $.1 . \Delta 9$ & $r$ & /.rq & QH & از كشت زنشاء كامل زمين و جمع أورى مواد زايد توسط ديسك و مسطح كردن و فشردن خاك قبل \\
\hline$\cdot / 4 T V$ & f & $\cdot / \cdot \Delta V$ & 1.re & ضدعفونى كردن ريشهها قبل از كشت جهت جلوگيرى از بيمارىهاى قارجى \\
\hline$\cdot /$. & $j^{r}$ & .1 .9 & $1 . \wedge \Delta$ & مطلوب در هر بوته خواصله و تراكم كشت كه به باعث بيشترين تعداد برك، خوشه، ميوه و عملكرد \\
\hline . /rrq & f & .1 .9 & $1 \cdot 1 r$ & كى كند. كيهاى و دو رديفه توتفرنكى كه نسبت به بوتهاى داخل رديف محصول بيشتر توليد \\
\hline$\cdot \mid k+1$ & f & .1 .9 & 1.91 & زهكشى مناسب خاك در سيستم كشت كيهاى به علت ارتفاع بستر كشت از سطح زمين \\
\hline . /rit & f &.$/ . \Delta F$ & 1.14 & دانش بومى كشاورزان در مورد كشت و كار توتفرنگى \\
\hline 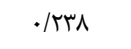 & r & .1 .9 & $1 \cdot \vee \wedge$ & رشد كامل ريشه در كشت ياييزه و سازكار شدن با خاك و ميوه دادن زودتر در سال آتى \\
\hline . / Q & r & $.1 \cdot \Delta 1$ & qr & مراقبت كمتر در كشت پِاييزه به دليل وارد شدن بوته به دوره استراحت \\
\hline . MFA & f & .1 .91 & 11.9 & كنترل آسانتر علفهاى هرز در روش كشت كيهاى \\
\hline.$/ \mu V$ & $\Delta$ & $\cdot / \cdot V r$ & וrrq & ميوهاى نوبرانه و جزو اولين ميوههاى بهارى \\
\hline$\cdot|r \Delta|$ & f & 1.9 & lirv & داشتن ارزش غذايى بالا به خصوص از لحاظ ويتامين ث و مواد معدنى \\
\hline 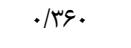 & Q & $\cdot 1 \cdot \mathrm{Vr}$ & $1 r \cdot 4$ & داشتن شكل و رنخ زيبا و عطر و طعم بالاى محصول \\
\hline.$/ T \& D$ & r & .1 .99 & 1198 & بازدهى سريع محصول در هنكام برداشت \\
\hline 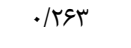 & f & .1 .99 & 119. & به دست آمدن ميوه با اندازه درشتتر (سرخوشه) در دورهى برداشت \\
\hline.$/ 10$ & r & $.1 \cdot \Delta$ & $q \cdot \vee$ & نقد شوندگى سريع محصول \\
\hline 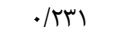 & f & $\cdot / \cdot \Delta \Lambda$ & 1.44 & عملكرد بالاى محصول در روش كشت كيهاى \\
\hline ו וא/. & f &.$/ . \Delta \wedge$ & $1.9 \mathrm{~V}$ & آتى لنه داشت بوتهها در زمين براى بوتهَّيرى و رويش بوتههاى جديد به عنوان نشاء در سال هاى \\
\hline r/Q人e & & & $11 \cdot 94$ & جمع \\
\hline
\end{tabular}

ضايعات محصول در فرآيند بازاررسانى، نياز آبى بالاى كياه در

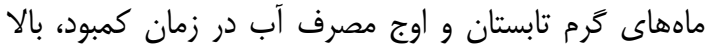

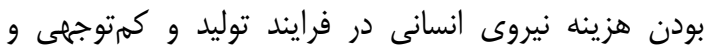
نظارت ضعيف ميدانى كارشناسان مسوول كشاورزى منطقه از فران اولويت بالايى برخوردار بودند.
نقاط ضعف زنجيرهى عرضهى توت توفرنئى

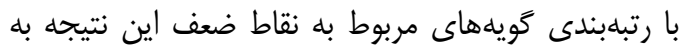

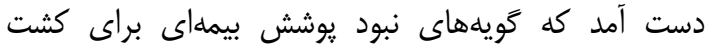

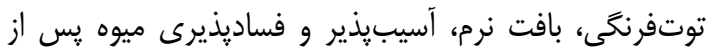
برداشت كه باعث كاهش ماندكارى مى شود.، بالا بودن مئن 
Table 3. Ranking the weakness of strawberry supply chain

جدول ؟- رتبلبندى نقاط ضعف زنجيرهى عرضهى توتفرنخى

\begin{tabular}{|c|c|c|c|c|}
\hline 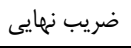 & رتبه & 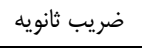 & ضريب اوليه & ضعفها \\
\hline.$/ \mathrm{AV}$ & r &.$/ \cdot 4 \mathrm{~V}$ & $1 \% 19$ & مكانيزه نشدن كشت توتفرنگى و كشت در فضاى باز و توليد به روش سنتى \\
\hline.$/ M A F$ & r & .1 .48 & ir.. & 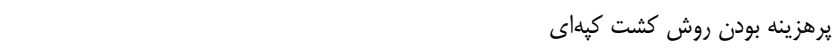 \\
\hline.$/ 194$ & r & $\cdot 1 \cdot+1$ & $1 \cdot \Delta \wedge$ & عدم انجام آزمايش خاك در زمان تهيه و آمادهسازى زمين قبل از كاشت \\
\hline .1110 & r & 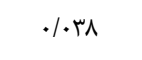 & ११४ & افزايش بيمارى نماتد ريشه به دليل كشت ساليانه و متوالى توتفرنغى \\
\hline.$/ 109$ & r & $.1+4$ & $1 . \mu \mathrm{c}$ & استفاده بيش از اندازه از كودهاى شيميايى كه منجر به مسموميت خاك مىشود. \\
\hline.$/ 1 \wedge 9$ & r & $.1 .+\mathrm{r}$ & TrוT & بالا بودن هزينه نيروى انسانى در فرآيند توليد \\
\hline .1110 & r &.$/ \mu^{\prime}$ & $1 . . r$ & عدم استفاده از خاكيوش جهت كنترل علف هرز و نوسان دماى خاك به دليل هزينههاى بالا \\
\hline.$/ 109$ & r &.$/ \cdot 4$ & $1 . r \mathrm{re}$ & عدم آكاهى كشاورزان از آفات و بيمارىهاى منطقه ع \\
\hline.$/ 1 \Delta V$ & f & $1 . \mu q$ & $1 . r \Delta$ & كه به مرور زمان باعث ايجاد انواع بيمارى هامها خواهد شايل حفاظتى در زمان سمياشى توسط كشاورزان \\
\hline .1 .99 & r & 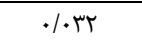 & NTr & عدم توجه به سلامتى مصرفكنندًان در هنگام فروش به علت استفاده از سموم با ماتدكارى بالا \\
\hline.$/ 194$ & c & $.1 \cdot 41$ & $1.9 \mathrm{~V}$ & عدم ارتباط كلاسهاى ترويجى موجود با نياز كشت و كار توتفرنكى \\
\hline /Nat & r & $.1+4$ & $1 \cdot \Delta 9$ & كمبود كارشناس متخصص ويرٌه توتفرنخى در منطقه \\
\hline.$/ \mathrm{Ve}$ & r &.$/ .4$ & $11 \% \mathrm{re}$ & كم توجهى و نظارت ضعيف ميدانى كارشناسان مسوول كشاورزى منطقه \\
\hline.$/ 1 \Delta S$ & c &.$/ .49$ & 1.r. & تمايل به انجام كارهاى نمايشى و ظاهرى توسط مسوولان كشاورزى \\
\hline .1199 & r & $\cdot 1 \cdot 41$ & $1 \cdot 14$ & ييشرس نبودن محصول به دليل هزينههاى جارى \\
\hline$\cdot / 1 \otimes \wedge$ & f &.$/ .4 q$ & $1 . r \Lambda$ & عدم حذف كرماى محصول به محض برداشت \\
\hline.$/ 11$. & r &.$/ .4 \mathrm{r}$ & $9 \Delta F$ & عدم بستهبندى و درجهبندى مناسب با سلايق مشتريان جهت فروش محصول \\
\hline.$/ 191$ & s & $\cdot 1 \cdot 4$ & $1 \cdot \Delta r$ & بالا بودن كرايه حمل كه منجر به پإيين آمدن سطح درآمد مىشود. \\
\hline$\cdot / \mathrm{\Lambda}$ & r & .1 .48 & 1194 & بالا بودن ضايعات محصول در فرايند بازار رسانى \\
\hline$. / T \Delta \mid$ & $\Delta$ &.$/ \cdot \Delta$ & $1 r \cdot \Lambda$ & نبود يوشش بيمهاى براى كشت توتفرنكى \\
\hline$\cdot / 1 \mathrm{~V}$ & r & . & 1119 & نداشتن مكان مناسب جهت خريد و فروش توتفرنگى \\
\hline$\cdot / 191$ & s & $\cdot 1 \cdot \uparrow \wedge$ & mere & بافت نرم، آسيبيذير و فساديذيرى ميوه پِ از برداشت كه باعث كاهش ماندكارى مىشود. \\
\hline$\cdot / 1 \wedge 1$ & r & $\cdot 1 \cdot 4 \Delta$ & $11 \mathrm{r} \wedge$ & نياز آبى بالاى گياه در ماههاى كرم تابستان و اوج مصرف آب در زمان كمبود \\
\hline.$/ 1 \Delta \Delta$ & r & $1.4 q$ & 1.14 & جديد مكان تناوب زراعى به دليل نكَه داشت بوتهها در زمين براى بوته كيرى و رويش بوتهاى \\
\hline$r / q \cdot \Delta$ & & & $r q \cdot 11$ & جمع \\
\hline
\end{tabular}

نهادههاى توليد (كود نيتروزن، يتاسيه، كود دامى، سموم

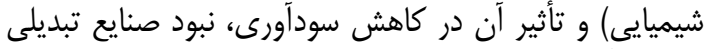

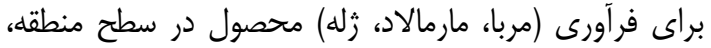

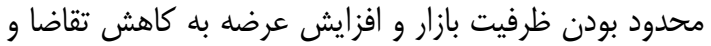

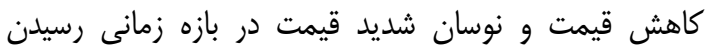

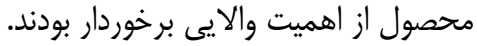

تهديدهاى زنجيرهى عرضهى توتفرنتى رئى

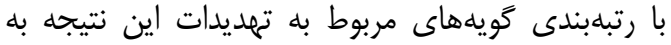

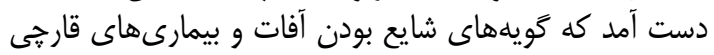

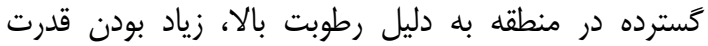

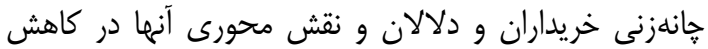

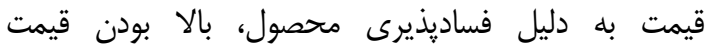


Table 4. Ranking the threats of strawberry supply chain

جدول ع- رتبهبندى تهديدهاى زنجيرهى عرضهى توتفرنكى

\begin{tabular}{|c|c|c|c|c|}
\hline ضريب نهايى & رتبه & ضريب ثانويه & ضريب اوليه & تهلديدها \\
\hline$\cdot / / 4$. & $\Delta$ &.$/ \cdot \Delta F$ & Imes & شايع بودن آفات و بيمارى هاى قارجى گَسترده در منطقه به دليل رطوبت بالا \\
\hline$\cdot / 1 \wedge \mid$ & r & $.1+4 \Delta$ & $1 \cdot 19$ & رقابت محصول توتفرنغى با ساير ميوههاى باغى زودرس در جذب سليقه مشترى \\
\hline.$/ 4 \pi$ & l & 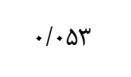 & Ir99 & زحصول بودن قدرت هانهزنى خريداران و دلالان و نقش محورى آنها در كاهش قيمت به علت فساديذيرى \\
\hline.$/$ MA & r & $.1+4$ & $11 \cdot r$ & نداشتن تسهيلات مناسب براى حمل و نقل مناسب توتفرنكى \\
\hline$\cdot / \mathrm{rr}$ & r & 1.4 & 1.4. & تغيير سلايق مشتريان به ساير ميوههاى باغى زودرس مانند هلو، آلو \\
\hline ./MN & c & .1 .48 & 1.98 & وجود حوادث طبيعى غير مترقبه مانند بارانهاى شديد، تخركى، برف \\
\hline.$/ \mathrm{V} \Delta$ & r & $.1 \cdot 44$ & 1.19 & افزايش آلودگى هاى محيطى به دليل كاربرد سموم شيميايى \\
\hline.$/ 119$ & r & .1 .4 . & १QT & فعال بودن سم فروشىهاى غيرمجاز در منطقه \\
\hline 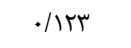 & r & $.1 \cdot 41$ & $94 \mu$ & سوء استفاده عرضه كنده نهادهها از عدم نقدينكى كشاورزان از نهاده \\
\hline$\cdot / \pi \mid$. & c &.$/ \cdot \Delta t$ & ITQV & كاهش سودآَرىى نهادهاى توليد (كود نيتروزن، پتاسيه، كود دامى، سموم شيميايى) و تأثير آن در \\
\hline.$/ 119$ & f & $.1 \cdot 4 \mathrm{r}$ & זrו1ו & كرانى تجهيزات بستهبندى (سلفون، ظروف، جعبه) در هنكام عرضه محصول \\
\hline 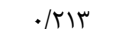 & r & ( & irVA & نبود صنايع تبديلى براى فرآورى (مربا، مارمالاد، زله) محصول در سطح منطقه \\
\hline$\cdot / r)$ & r &.$/ \cdot \Delta r$ & ITET & نبود تشكل و تعاونى براى توليدكندكان توتفرنكى \\
\hline.$/ M M$ & r &.$/ .+\mathrm{V}$ & $111 \% 9$ & نداشتن مكان مناسب (بازار קهها، ايستخاههاى فروش) در سطح منطقه \\
\hline$\cdot / t \cdot 4$ & r &.$/ \cdot \Delta$ & $|r|$. & نبود وسايل حمل و نقل مناسب (كاميونهاى يخهالدار) هنگام انتقال محصول به خارج از استان \\
\hline$\cdot / K I$. & c &.$/ \cdot \Delta t$ & ITQA & محدود بودن ظرفيت بازار و افزايش عرضه به كاهش تقاضاو كاهش قيمت \\
\hline$\cdot / r \cdot 1$ & r &.$/ \cdot \Delta T$ & IMFA & نوسان شديد قيمت در بازه زمانى رسيدن محصول \\
\hline$\cdot /$ MA & r & .1 .48 & 11.9 & نبود تسهيلات بانكى براى توسعه سطح زير كشت \\
\hline.$/ \wedge \Delta$ & r & .1 .48 & $11 \cdot 1$ & بيمارى در منطقة مطالعات يُوهشى توسط مراكز علمى و يُوهشى در زمينه معرفى ارقام مقاوم به آفات و \\
\hline.$/ 1 V r$ & r & 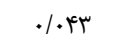 & $1 . r 9$ & وقوع نامنظم سرما غيرقابل ييشبينى و شدت آن \\
\hline.$/ I V A$ & r & 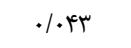 & 1. Kr & تأخير در نقد شوندگى محصول و كمبود نقدينكى \\
\hline r/qVa & & & r & جمع \\
\hline
\end{tabular}

و فرآورى توتفرنكى (مربا، مارمالاد و ...)، امكان اجراى

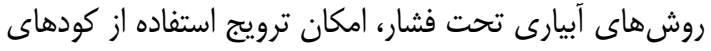

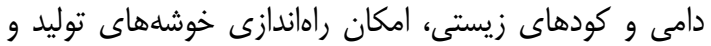
فرآورى توتفرنكى از اهميت بالاترى برخوردار بودند.
فرصتهاى زنجيرهى عرضهى توت توفرنكَى

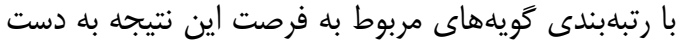

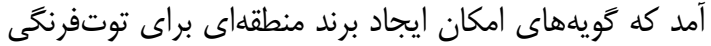

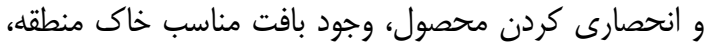
امكان ايجاد صنايع جانبى و توسعه كار آفرينى در فرايند توليد 
Table 5. Ranking the opportunities of strawberry supply chain

جدول ه- رتبلبندى فرصتهاى زنجيرهى عرضهى توتفرنگى

\begin{tabular}{|c|c|c|c|c|}
\hline ضريب نهايى & رتبه & ضريب ثانويه & ضريب اوليه & فرصتها \\
\hline.$/ 1 \Lambda \&$ & f & .1 .48 & $11 \mathrm{r}$. & امكان ايجاد برند منطقاى براى توتفرنكى و انحصارى كردن محصول \\
\hline.$/ M A t$ & r & .1 .48 & $\mid 101$ & 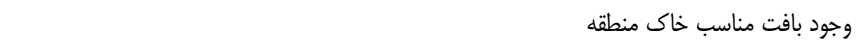 \\
\hline.$/ 19 V$ & f & . & 1. Qt & وجود شرايط اقليمى مناسب در منطقه \\
\hline.$/ I V V^{2}$ & f & re & 1.99 & امكان ايجاد جشنوارههاى محلى گستردهتر در منطقه \\
\hline.$/ 1 r$. & r & $.1 \cdot 4$ & $1 . .9$ & ايجاد بازارجههاى محلى و ايستخاههاى فروش كنار جادهاى \\
\hline.$/ 114$ & r & . & 991 & امكان صادرات به كشورهاى همسايه به علت نزديكى شرق استان به مرز \\
\hline.$/ 19 V$ & f & Lte & $1 \cdot \Delta t$ & امكان ايجاد تعاونى و اتحاديههاى توليد و فروش محصول \\
\hline.$/ 191$ & r &.$/ .+1$ & $I T \cdot \Delta$ & (مربا، مارمالاد و..) ) ايعاد جانبى و توسعه كارآفرينى در فرايند توليد و فرآورى توتفرنگى \\
\hline.$/ 111$ & r &.$/ \cdot r q$ & qur & امكان ايجاد سردخانهاى مخصوص قبل از بستهبندى محصول براى افزايش سودآورى \\
\hline.$/ 114$ & r &.$/ \cdot r t$ & $9 F \Delta$ & امكان كشت و كار توتفرنگى در كلخانه جهت جلوكيرى از آسيبهاى احتمالى \\
\hline.$/ 1 \mathrm{Vq}$ & f & $.1 \cdot+\Delta$ & $11 r 9$ & افزايش علاقه و تمايل مردم به مصرف محصول توتفرنكى \\
\hline$\cdot / \mathrm{Vr}$ & f & 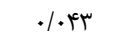 & 1.94 & امكان ترويج فنون نوين كشت توتفرنگى \\
\hline.$/ 111$ & r &.$/ \cdot r q$ & १९ा & بهرهمندى مناسب مراكز خدمات از تجارب و همكارى كشاورزان با تجربه در زمينه كشت محصول \\
\hline.$/ 1 \mathrm{VV}$ & f & $.1 \cdot 44$ & 1119 & افزايش جذابيت بستهبندى \\
\hline.$/ M A t$ & f & .1 .48 & 1101 & امكان برداشت صحيح محصول و در زمان مناسب كه باعث كاهش ضايعات محصول خواهد شد. \\
\hline.$/ 1 V \Delta$ & f & $.1 \cdot 4 t$ & $11 . \mathrm{r}$ & آموزش كشاورزان جهت توليد و برداشت صادراتى، نحوه קيدن و سرد كردن مقدماتى محصول \\
\hline.$/ 1 V \Delta$ & r & $.1 \cdot+4$ & $11 \cdot 0$ & رعايت نكات بهداشتى در بستهبندى \\
\hline.$/ M A t$ & f & $\cdot 1 \cdot 4 \Delta$ & llev & امكان اجراى سيستمهاى آبيارى تحت فشار \\
\hline.$/ \Lambda \mu$ & r & .1 .48 & $11 \otimes \omega$ & امكان ترويج استفاده از كودهاى دامى و كودهاى زيستى \\
\hline .1199 & r & 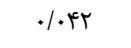 & $1.9 \mathrm{~V}$ & رعايت سفارشات مشترى و حجم ميوه مورد نظر \\
\hline.$/ \cdot \Delta V$ & t & $.1 \cdot r \Lambda$ & VIV & امكان كاربرد تجارت الكترونيك در زمينه عرضه و فروش محصولات \\
\hline.$/ M A t$ & r & $.1 \cdot 4 \Delta$ & $111 \%$ & امكان راماندازى خوشههاى توليد و فرآورى توتفرنگى \\
\hline.$/ 119$ & r & .1 .49 & $9 \gamma^{e}$ & امكان كنترل زيستى محصول و كاهش استفاده از سموم شيميايى \\
\hline .1 .9$. & r & $\cdot \cdot \cdot r \cdot$ & $V \Delta S$ & امكان توليد و يرورش زنبور عسل \\
\hline 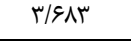 & & & TATYA & جمع \\
\hline
\end{tabular}

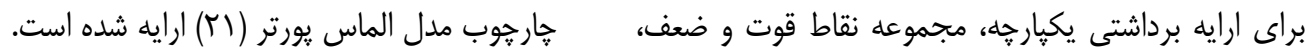

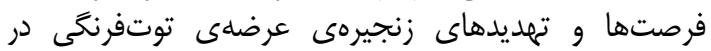

Table 6. Explaining the supply chain of strawberries in porter diamond

جدول צ- بازتبيين زنجيرهى عرضهى توتفرنكى در خار خوب مدل الماس يورتر

\begin{tabular}{|c|c|}
\hline ضعفها & قوتها \\
\hline - نبود يوشش بيمهاى براى كشت توتفرنكى & - ميوماى نوبرانه و جزو اولين ميوههاى بهارى \\
\hline - بافت نرم، آسيبذيذير و فساديذيرى ميوه ِّد از برداشت كه باعث كاهش ماندكارى & - داشتن شكل و رنغ زيبا و عطر و طعم بالاى محصول \\
\hline - بالا بودن ضايعات محصول در فرايند بازار رسانى & - به دست آمدن ميوه با اندازه درشتتر (سرخوشه) در دورهى برداشت \\
\hline - نياز آبى بالاى گياه در ماههاى گرم تابستان و اوج مصرف آب در زمان كمبود & - بازدهى سريع محصول در هنكام برداشت \\
\hline - كم توجهى و نظارت ضعيف ميدانى كارشناسان مسوول كشاورزى منطقه & \\
\hline - بالا بودن هزينه نيروى انسانى در فرايند توليد & \\
\hline تهديدها & فرصتها \\
\hline - شايع بودن آفات و بيمارىهاى قارجى گسترده در منطقه به دليل رطوبت بالا & - ايجاد برند منطقهاى براى توتفرنكى و انحصارى كردن محصول \\
\hline - زياد بودن قدرت جانهزنى خريداران و دلالان و نقشل محورى آنها در كاهش قيمت به & - - وجود بافت مناسب خاك منطقه \\
\hline - بالا بودن قيمت نهادهاى توليد (كود نيترورن، يتآسيهي، كود دامى، سموم شيميايى) و & - امكان ايجاد صنايع جانبى و توسعه كارآفرينى در فرآيند توليد و فرآورى \\
\hline - نبود صنايع تبديلى براى فرآورى (مربا، مارمالاد، زله) محصول در سطح منطقه & - امكان اجراى روشهاى آبيارى تحت فشار \\
\hline - نبود تشكل و تعاونى براى توليدكنندًان توتفرنكى & - امكان ترويج استفاده از كودهاى دامى و كودهاى زيستى \\
\hline - محدود بودن ظرفيت بازار و افزايش عرضه به كاهش تقاضا و كاهش قيمت & - امكان راهاندازى خوشههاى توليد و فرآورى توتفرنگى \\
\hline - نوسان شديد قيمت در بازه زمانى رسيدن محصول & \\
\hline
\end{tabular}




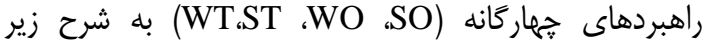

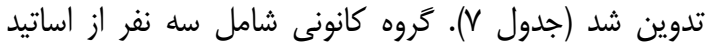

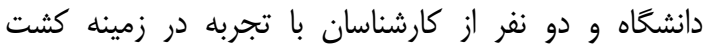

توتفرنكى از مديريت جهاد كشاورزى شهرستان اندان راميان بود.
يس از شناسايى نقاط قوت، ضعف، فرصت و تهايد

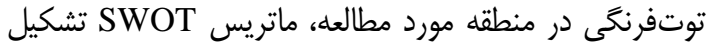

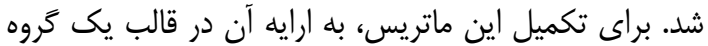
كانونى اقدام و بر مبناى نتايج حاصل، سياستهایى مئ متناظر

جدول V- سياستهاى مرتبط با راهبرد جهار كانه در خارجوب ماتريس SWOT Table 7. Policies related to quadruple strategies whitin the frame work SWOT

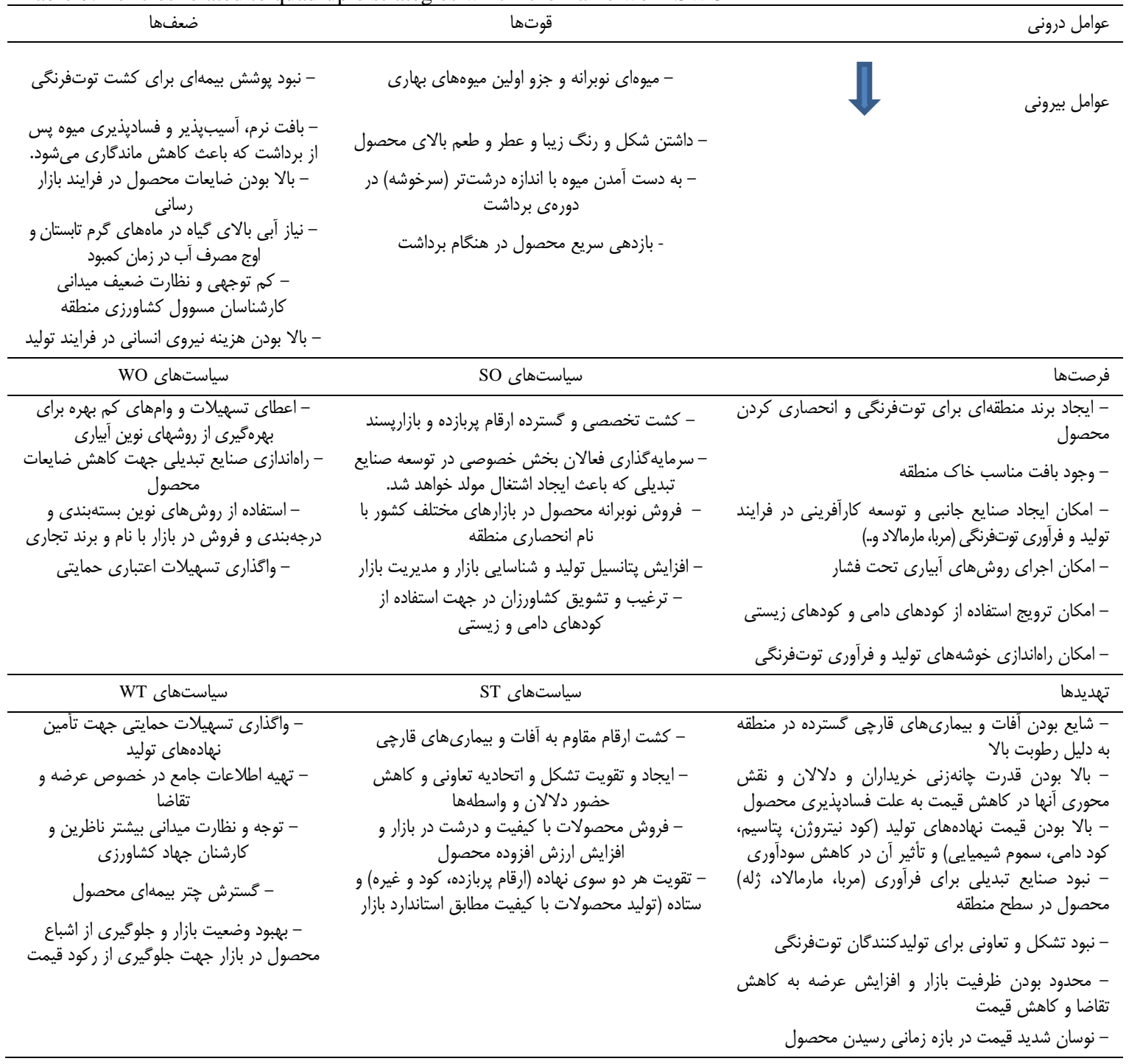

دستاندركاران بايستى تلاش كنند از نقاط ضعف و تهديدها كاسته و به سمت اين راهبردها كانس كام بردارند.
با توجه به نتايج به دست آمده (شكل r)، راهبردهاى توليد توتفرنكى به راهبردهاى تدافى نزئ نزديك است. بنابراين، 


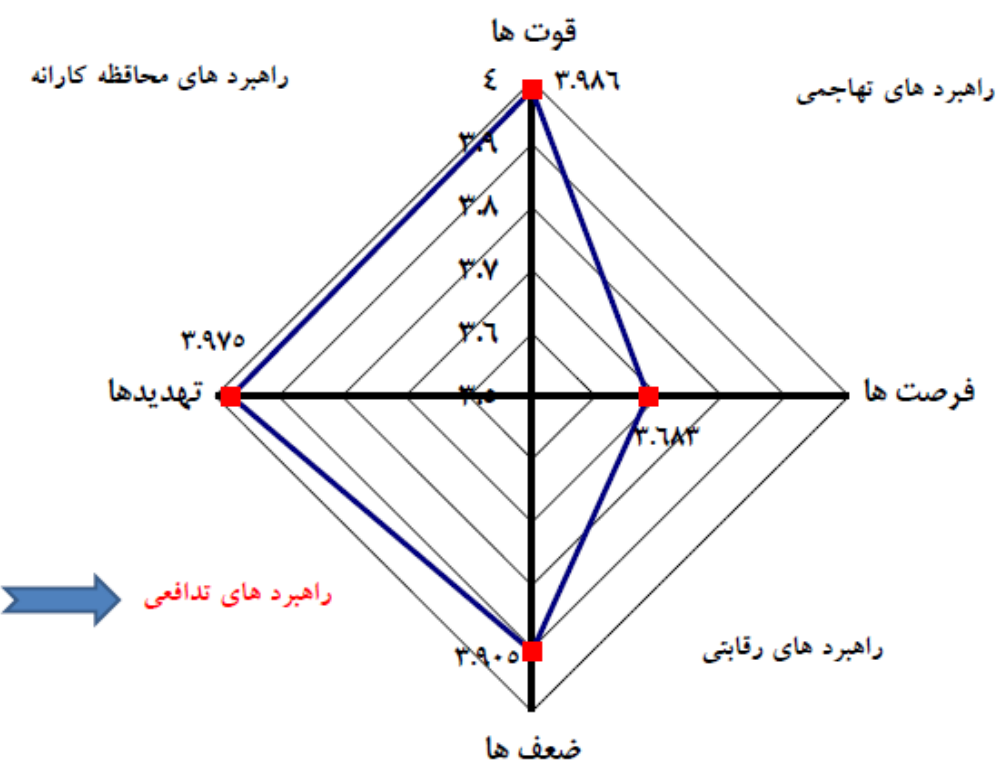

شكل r- مكانيابى وضعيت زنجيرهى عرضهى توتفرنخى در دستخاه مختصات راهبردى

Figure 2. Locating the status of strawberry supply chain in a strategic coordinate system

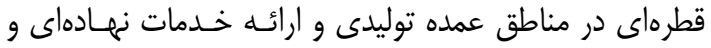

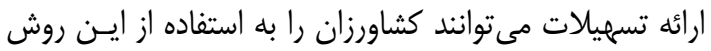

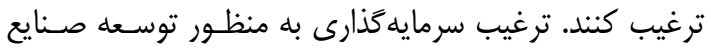

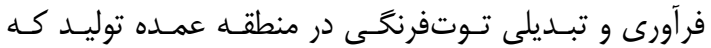

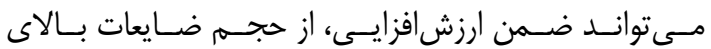

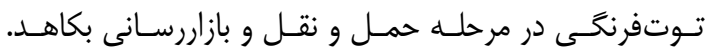

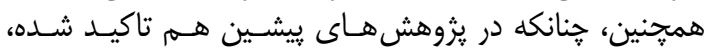

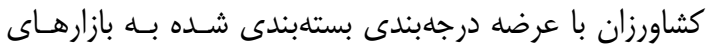

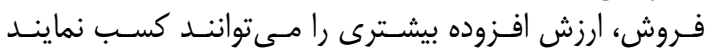

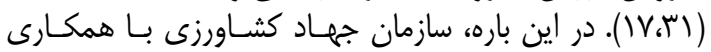

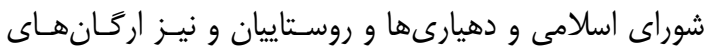

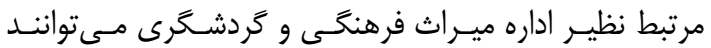

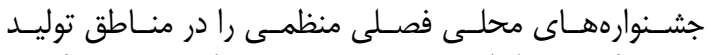

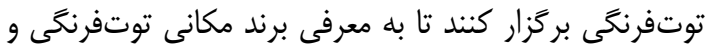

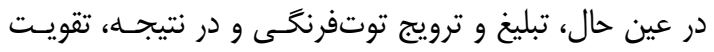
اقتصاد محلى كمى شود.

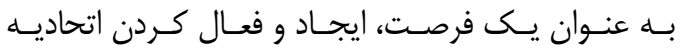

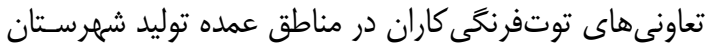

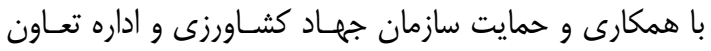

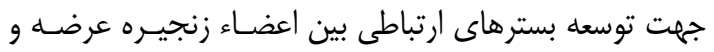

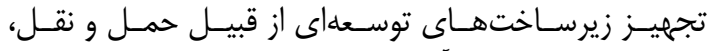

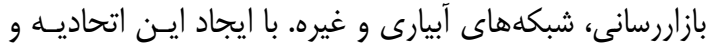

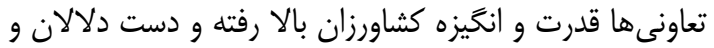

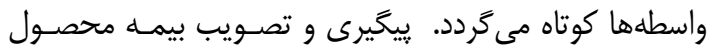

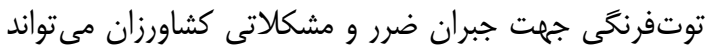

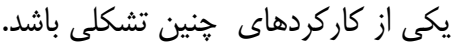

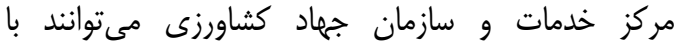
همكارى كشاورزان اطلاعات جامعى در خان خصوص وضعيت
نتايج تحقيق حاكى از اين است كه نحوه كشت تمامى

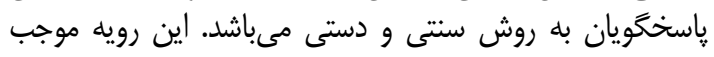

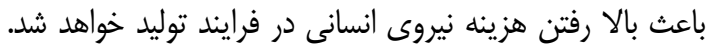

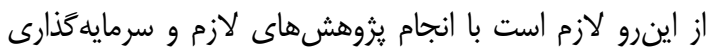

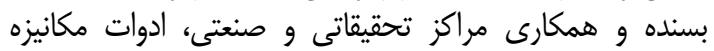

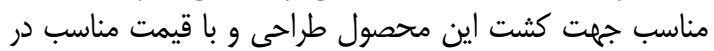
دسترس كشاورزان قرار كيرد.

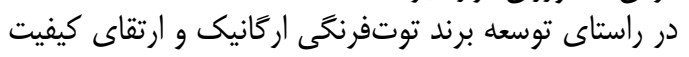

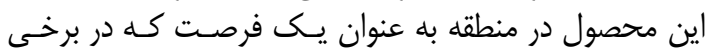

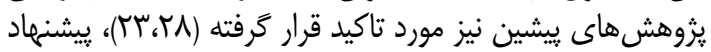

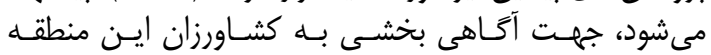

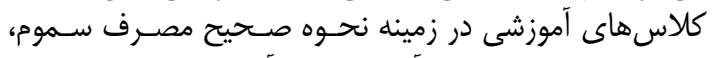

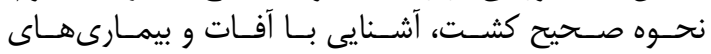

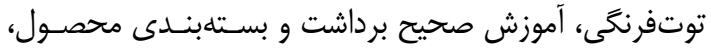

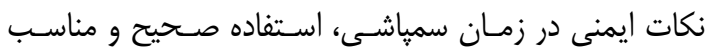

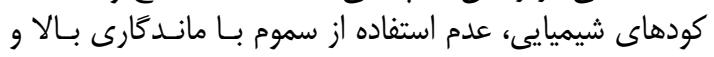

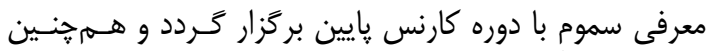

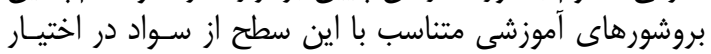

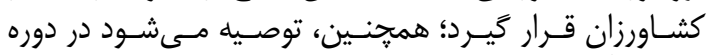

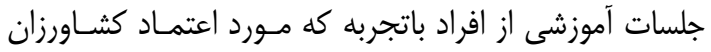

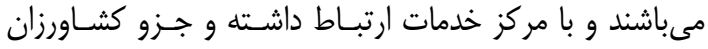

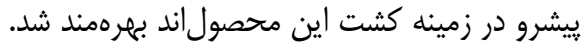

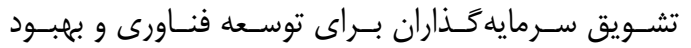

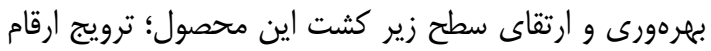

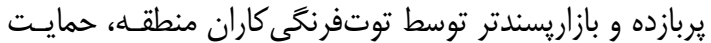

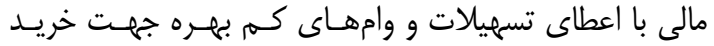

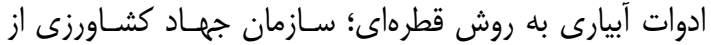

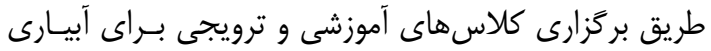




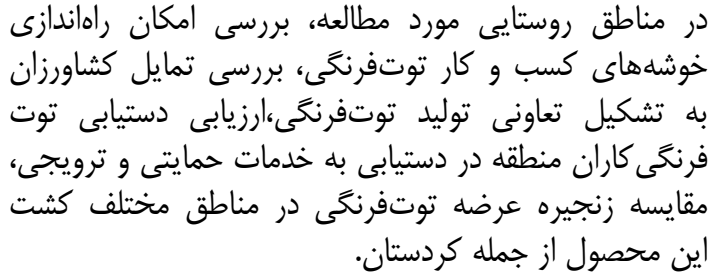

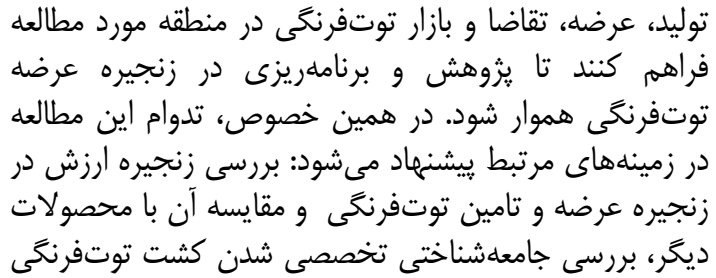

1. Aghajani, H.A. and K. Ravanestan. 2014. Investigating the effect of provision components on supply chain management on organizational performance indicators by structural equation modeling (Case study: Automotive electronics industry of Iran). Industrial Management, 6(2): 230-209 (In Persian).

2. Ahmadi, F. 2011. Evaluation of cotton supply chain performance in Golestan province using Swot method. Master's thesis, Faculty of Basic Sciences and Agriculture, Payame Noor University (In Persian).

3. Ahumada, J. and R. Villalobos. 2009. Application of planning models in the agri-food supply chain: A review. European Journal of Operational Research, 195(1): 1-20.

4. Amiri, H. 2008. Investigating the competitiveness of saffron supply chain with emphasis exchange cost economic approach. Report on research project. Tehran: Research Institute for Human and Social Sciences (In Persian).

5. Amin Naseri, M.R., M. Moradi and S.A. Malihei. 2008. Macro-architecture of Iranian tea supply. Commercial Research Journal, 12(46): 143-119 (In Persian).

6. Chopra, S. and P. Mendl. 2001. Supply chain management. Upper Saddle River, NJ, Prentice-Hall, Inc, 33-37.

7. David, F.R. 2010. Strategic Management, translation by Ali Parsaeean and Seyyed Mohammad Arabi. Tehran: Publication of the Office of Cultural Research.

8. Faraji, M. and M.A. Dabbagh Maneshe. 2006. Investigating the causes of impacting on the moldability of supply chain of silk production and processing Industry in order to identify problem and provide appropriate solutions. Goljam, Journal of the Iranian Carpet Association, (67): 79-106 (In Persian).

9. Getachew. D.W.. L. Zemedu and A. Wassie. 2016. Mushroom value chain analvsis in Addis Ababa, Ethiopia. Journal of Agricultural Extension and Rural Development, 8(8): 130-140.

10. Golkar, C. 2006.The application of swot technique for application in urban design. Seif Scientific Research Journal (41): 1-21 (In Persian).

11. Harrison, J.S. and C.H. St. John.2002. Foundations in Strategic Management, (2nd ed.), Cincinnati: South Western Publishing Company. 234 pp.

12. Hosseini, S.M. and N. Sheikhi. 2011. Explaining the strategic role of supply chain management operations to improve company performance (Case Study of Iran's Food Industry). Strategic Management Studies, (10): 60-35 (In Persian).

13. Humphrey, J. 2015. Shaping Value Chains for Development: Global Value Chains in Agribusiness, GTZ, Eschborn pub, Germany. $186 \mathrm{pp}$

14. Jadav, K.S., A.K. Leua and V.B. Darji. 2011. Economic analysis of supply chain of fresh potato in middle Gujarat. Indian Journal of Agricultural Research, 45(4): 266-274.

15. Khaledi, M. and A. Amjadi. 2009. Importance and application of supply chain management in the agricultural and related Industries. Article presented to the $7^{\text {th }}$ Biennial Conference on Agricultural Economics, Tehran, Karaj, 13 pp (In Persian).

16. Khaledi, M., S. Lotfi and G.R. Yavari. 2013. Investigating the performance of onion supply chain in East Azarbaijan Province. Commercial Reviews, 11(58): 79-68 (In Persian).

17. Lei, D., R. Wang, T. Dong and Mu. Weisong. 2016. Assessing the table grape supply chain performance in China - a value chain analysis perspective. British Food Journal, 118(5): 1129-1145.

18. Marsden, Terry, Jo Banks, Gillian Bristow. 2000. Food Supply Chain Approaches: Exploring their Role in Rural Development. Sociologia Ruralis, 40(4): 424-438.

19. Negi, S. and N. Anand. 2015. Issues and challenges in the supply chain of fruits and vegetables sector in India: A Review. International Journal of Managing Value and Supply Chains, 6(2): 47-62.

20. Paraj, H. 2011. Study of soybean supply chain performance in Golestan Province. Master's thesis, Faculty of Agriculture, Payame Noor University (In Persian).

21. Porter, M.E. 1985. Competitive advantage. The Free Press.

22. Puryoosof, A. and M. Saghafi. 2017. Value chain development strategies in production cooperatives (studied by South Cooperative South Khorasan). Supply Chain Management, 19(55): 65-49 (In Persian).

23. Pye-Smith, C. 2013. Policy Pointer: Value Chains for transforming smallholder. Wageningen, Netherlands: CTA. 15-19 pp.

24. Rahman Seresht, H. and A. Afsar. 2008. The effect of information sharing on competitive strategies and supply chainperformance. Information Technology Management, 1(1): 48-37 (In Persian). 
25. Rahmani, D. and M. Taherkhani. 2006. An analysis of the specialization of cropping pattern and its role in rural development. Case Study: strawberry cultivation in Javaroud region of Marivan . Human Sciences MODARES, 10(1): 102-81 (In Persian).

26. Rastegari, H. and M. Nouripour. 2012. Analysis of the influence of information and communication technology on the supply chain of agricultural products (Case study: central part of Falavarjan city). Agricultural Promotion and Education Research, 34(2): 34-21 (In Persian).

27. Reddy, G.P., M.R.K. Murthy and P.C. Meena. 2010. Value chains and retailing of fresh vegetables and fruits, andhra pradesh. Agricultural Economics Research Review, 23: 455-460.

28. Rieple, A. and S. Rajbir. 2010. A value chain analysis of the organic cotton industry: The case of UK retailers and Indian suppliers. Ecological Economics, 69(11): 2292-2302.

29. Shahibandarzadeh, H., G.R. Jamali. and F. Shafiei. 2013. An analytical approach in identifying factors affecting supply chain risk in dairy industry. Supply Chain Management, 15(42): 53-42 (In Persian).

30. Vroegindewey, R. and J. Hodbod. 2018. Resilience of Agricultural Value Chains in Developing Country Contexts: A Framework and Assessment Approach. Sustainability (10): 916: 1-18.

31. Waldron, S., C. Brown. and A.M. Komarek. 2014. The Chinese Cashmere Industry: A Global Value Chain Analysis. Development Policy Review, (32): 589-610. 


\title{
Strawberry Supply Chain Analysis in Ramiyan County, Golestan Province
}

\section{Marziye Miri ${ }^{1}$, Mohammad Sharif Sharifzadeh ${ }^{2}$, Gholamhossein Abdollahzadeh ${ }^{3}$ and Ahmad Abedi Sarvestani ${ }^{4}$}

\author{
1- Master of Science in Agricultural Extension and Education \\ 2- Associate Professor, Faculty of Agricultural Management, Gorgan University of Agricultural Sciences and Natural \\ Resources, (Corresponding Author: sharifsharifzadeh@gmail.com) \\ 3- Associate Professor, Faculty of Agricultural Management, Gorgan University of Agricultural Sciences and Natural \\ Resources \\ Received: October 29, $2018 \quad$ Accepted: February 3, 2019
}

\begin{abstract}
This research was carried out to analyze Strawberry Supply Chain in Ramin County, Golestan Province. The statistical population of this research included all strawberry farmers in Ramian County $(\mathrm{N}=1100)$. According to Krejcie and Morgan's sample size table, sample size was determined $(\mathrm{n}=289)$. The respondents were selected by simple random sample technique. Content and formal validity of the researcher-made questionnaire as research tool was approved by an expert panel, including a group of faculty members and extension agents. Some items have been removed or merged to increase the validity of the questionnaire. Its reliability was confirmed by calculated Cronbach's alpha coefficient (between 0.72 and 0.90 ). This research applies mixed methods. The first and second phases were used quantitative and qualitative research method. The findings of the first phase were used to describe the issue and generalities of the research design as well as the development of research tools in the second phase. The results of the ranking items showed that "being fresh fruit and premature" as a strength, "the lack of insurance for the cultivation of strawberry" as weakness, "the prevalence of extensive fungal pests and diseases in the region due to high humidity" as a threat and "the possibility of creating the complementary industries and entrepreneurship development in the process of production and processing of strawberries (jam, marmalade, etc)" as opportunity have high priorities. The total score of the internal factors (strengths and weaknesses) was 3.986 and 3.905 , respectively, and the total score of the external factors (opportunities and threats) was 3.683 and 3.975 respectively. According to the results, supply chain development strategies are close to defensive strategies. Using a focused group approach, a set of policies was introduced for each strategy. According to the results of the study, we can suggest promoting more productive and marketable varieties by growers in the region, encouraging investment in order to develop the processing and conversion industries in the area which, as well as the creation and activation of a union of cooperatives.
\end{abstract}

Keywords: Mixed-methods, Ramian County, Supply Chain, Strawberry Production 